\title{
HYSTERESIS BEHAVIOR OF SEISMIC ISOLATORS IN EARTHQUAKES NEAR A FAULT IN ECCENTRICALLY BRACED FRAMES WITH VERTICAL AND HORIZONTAL LINKS
}

\author{
M. A. Dehvari Dehaki ${ }^{1}$, P. Azmoon ${ }^{2}$, F. Azmoon ${ }^{3}$, A. Seddiqpour ${ }^{4}$ and N. Dehvari Dehaki ${ }^{5}$
}

${ }^{1}$ Master in structural engineering, member of the Scientific Board of Saravan Azad University

${ }^{2}$ Master in structural engineering, lecturer in Islamic Azad University of Bam, expert in Kerman province's administration of standard

${ }^{3}$ Master in architectures, lecturer in Islamic Azad University of Bam, member of Young Researchers Club

${ }^{4}$ Master in hydraulic structures, member of the Scientific Board of Islamic Azad University of Bam

${ }^{5}$ Master in Teaching English Language, lecturer in Islamic Azad University of Saravan

\begin{abstract}
Seismic performance and appropriate design of structures located near the faults has always been a major concern of design engineers. Because during an earthquake; the effects of plasticity will make differences in characteristics of near field records. These pulsed movements at the beginning of records will increase the maximum acceleration, speed and displacement which create unconventional forms in the response spectrum and apply a lot of energy to the structure. Appropriate lateral loading systems were proposed to eliminate the hardness and ductility at the same time and provide more acceptable systems in this field. One of these systems is the eccentrically braced frames systems in which seismic performance is based on link beam.
\end{abstract}

Author Correspondence, e-mail: authorC@gmail.com doi: http://dx.doi.org/10.4314/jfas.v8i3s.173 
However, any pulsed movements in the near field records in this system will be followed by unusual behavior. This type of behavior has been controlled by advancement of technology and creation of vibration control systems because the earthquake forces are indirectly applied to the structure. For further investigations about this issue in this study, some traditional twodimensional frame in 4, 8 and 12 floors were modeled using seismic isolators and then by applying nonlinear analysis and near field earthquake records, their hysteresis behaviors were studied.

Keywords: hysteresis curve; near-fault records; eccentrically braced frames; link beam.

\section{1- INTRODUCTION}

Near-fault earthquake issue is almost a new issue in earthquake engineering. Recently, many studies have been done about the behavior of structures affected by near-fault earthquakes and comparison of them with far-fault earthquakes [1]. Near-fault earthquakes have caused too many damages. Differences in the parameters of the earth in near-fault earthquakes and also differences of structural behaviors near faults, have caused near-fault earthquakes to be important in both earthquake engineering and seismology perspectives. Researches on the records gained by world seismic network, has specified the geographical conditions of the location of the site and differences of near-fault records and far-fault records, which has made the professors of this science to pay more attention to this issue [2]. Near-fault records that are also called pulsed records, are known as the records that cause severe damages to the structures and may be very strong. Specifications of these records are different from normal records and mostly contain a long-period pulse in the beginning of a record in short time interval. Mentioned pulse contains most of the seismic energy caused by rupture and creates an unusual form in response spectrum of these records [2]. What is so special in the near-fault earthquakes speed records, is the incremental large speed of the earth which is caused by long-term momentum pulses. An expression of these effects is the large fluctuation deformation which can be also seen in ground movement record. These large amounts of near-fault ground motion parameters, are the main characteristics of earthquake records such as Northridge earthquake, Kobe earthquake, Chi-Chi earthquake in Taiwan and near-field earthquake faults, or in other words, the faults near the seismic faults [3]. There is a record from Park-field earthquake in California in 1966, c02 station which is the first record in which the effect of seismic source is specified. The main characteristics of this record, are displacement pulses and extreme speed, with a relatively large period, that is completely 
different from far-field records [4]. Hans and Trifonak first observed this in 1967 and after a year Aki simulated the ground motion using simple fault models, which was a turning point in earthquake engineering [4]. Some studies show that near-fault earthquake records and be divided into two parts, with and without pulse rates and in some cases, pulse phenomenon in the history of acceleration, velocity and displacement is a feature that distinguishes near-fault areas from far-fault areas [5]. Pulses in earthquake are defined as acceleration pulse, velocity pulse and displacement pulse which can be also defined as big changes in history of acceleration, velocity and displacement. From then on, records of important earthquakes have stressed the existence of these pulses in the areas near the fault and their damage potential when the fault is in the vicinity of urban areas. Barter et al. were the first engineers to discover this issue in 1987 and applied its effects on the structures [4]. After the 1994 Northridge and 1995 Kobe earthquakes, many modern structures had taken serious damages or totally destroyed, although those countries had advanced regulations for seismic design of structures at that time [4]. Structures are subjected to strong ground vibrations, especially the vibrations that occur in a long time will incur a large number of roundtrips. In normal structures, stiffness is reduced after some reciprocating motions. So stiffness reduction must be noticed in earthquake-prone areas. In sequential loading cycles in traditional systems, by reduction of stiffness, more deformations are shown compared to the structures that lack stiffness or strength reduction. Prerequisite for their sustainability is to tolerate more deformations in next cycles [6]. But ground seismic motions will cause big accelerations in floors in stiff structures and displacement in soft structures. These difficulties on one hand and the need to increase the safety of structures against earthquake on the other hand, have increased the importance of studying and application of active and passive vibration control systems [7]. In active control systems, structures will directly face lateral forces and since during the useful life of the structures, they frequently enter inelastic area and create lasting deformations, they will cause serious damages to structural and non-structural parts. Therefore, these systems are replaced with passive control systems. Both systems have a certain popularity, because they create a proper relationship between hardness and ductility. Eccentrically braced frame systems with horizontal and vertical beams can be noted as the systems with higher acceptances [8, 9, and 10]. In this type of systems, seismic performance is related to link beam and its design plays an important role in elastic performance of the structure. Position of link beams are different in common frames and they can be divided into vertical and horizontal types [11]. In active vibration control systems, seismic forces increase 
structural damping indirectly and by using mechanical damper and kinetic energy of earthquake is amortized by these dampers without doing any damage to structural parts. Using mechanical dampers in addition to increasing energy amortization capability, also reduces structural response in earthquakes and in this way, they decrease the damages to nonstructural parts. One of these dampers which have been done a lot of studies about, are seismic isolators in structure's foundation and frames with vertical link beam [8, 9 and 10]. The increasing use of this type of isolators, especially in near-fault areas and integration of these systems with resistant traditional structures and getting to know to their performances in near-fault earthquakes are some aims of this study.

\section{2- NONLINEAR DYNAMIC ANALYSIS}

In nonlinear analysis, structural response is calculated by nonlinear geometric behavior of the structure. Accelerograms used to determine the effect of ground motion in this study, were three pairs of Northridge, Kobe and Tabas accelerograms. Features of these accelerograms are mentioned in table 1.

\begin{tabular}{|c|c|c|c|c|c|c|}
\hline \multirow{2}{*}{ Earthquake } & \multirow{2}{*}{ Station } & $P G A 00$ & PGA90 & PGV00 & PGV90 & \multirow{2}{*}{$\begin{array}{l}\text { Closest to fault rupture } \\
\mathrm{km}\end{array}$} \\
\hline & & \multicolumn{2}{|c|}{$g$} & \multicolumn{2}{|c|}{$\mathrm{cm} / \mathrm{s}$} & \\
\hline $\begin{array}{c}\text { Northridge } \\
1994\end{array}$ & Sylmar & 0.61 & 0.9 & 117.43 & 102.21 & 6.2 \\
\hline $\begin{array}{r}\text { Kobe } \\
1995\end{array}$ & Takatory & 0.61 & 0.61 & 127.16 & 120.73 & 0.3 \\
\hline $\begin{array}{c}\text { Tabas } \\
1978\end{array}$ & Tabas & 0.84 & 0.85 & 97.76 & 121.22 & 2.05 \\
\hline
\end{tabular}

These accelerograms that meet the conditions in paragraph 1-4-1-4-2 in regulation no. 2800, must be scaled according to paragraph 2-4-1-4-2 and finally combined response spectra of three accelerogram pairs must be averaged and compared to standard design spectrum with time intervals of T1.5 and T0.2. Scale factor must be determined in a way that in this range, average values should not be 4.1 times lesser than the amount in standard spectrum (Figure 1). 


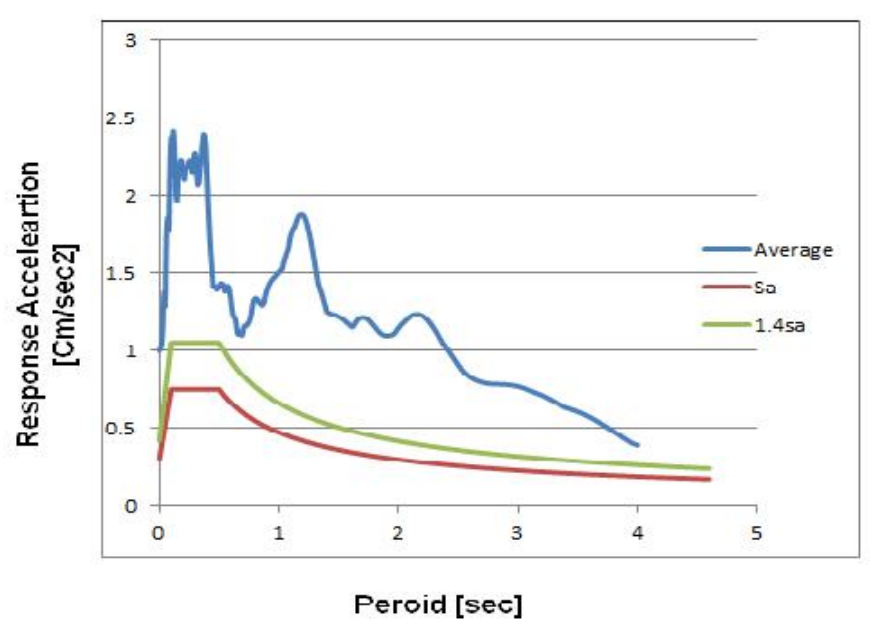

Fig.1. Averaging combined spectrum with standard spectrum

\section{3- THE STUDIED MODELS}

The models used in this study were eccentrically braced steel frames with horizontal and vertical links in 4,8 and 12 floors. The links were fixed and their length were 4.0 meters. These frames have three spans with the same length of 5 meters and constant height of 3 meters on each floor (Figure 2). According to the purpose of the study, this structure is assumed as great importance and above models are applied on soil type 2 and gravity and seismic loads are based on sixth issue of National Building Regulations and 2800 standard, $3^{\text {rd }}$ edition [12]. Then under regulations of UBC [13], the structures were designed in software and the models were prepared for sap2000 program for nonlinear dynamic analysis. Models have been prepared in two types of "fixed based" and "isolated". In isolated models, seismic isolation specifications, which is LBR type, is attributed by RUBBER element to the models and according to journal 523 [14], specifications of these isolators are given below. After allocating the plastic joints according to development guideline and FEMA356 regulations [14, 15 and 16], the models will finally be nonlinear statically and dynamically analyzed. Frames are classified according to the type and number of floors. 3 characters were used for naming. First character indicates the type of the frame. " $\mathrm{C}$ " is for frames with fixed base and "R" is for frames with isolated base. Second character indicates the number of the floors and last character indicates eccentrically braced frame to show if it has vertical or horizontal link. For example, table 2 shows two frames with fixed and isolated bases. 
Table 2. Naming the eccentrically braced frame with normal and fixed bases

\begin{tabular}{|c|c|c|c|}
\hline $\begin{array}{r}\text { Frame } \\
\text { name }\end{array}$ & $\begin{array}{r}\text { Character } \\
\text { number }\end{array}$ & $\begin{array}{r}\text { Character } \\
\text { type }\end{array}$ & Comment \\
\hline \multirow{3}{*}{ C4EBF } & $\begin{array}{r}\text { First } \\
\text { Character }\end{array}$ & $\mathrm{C}$ & Frame with fixed base \\
\hline & $\begin{array}{r}\text { Second } \\
\text { Character }\end{array}$ & 4 & Number of the floors \\
\hline & $\begin{array}{r}\text { Third } \\
\text { Character }\end{array}$ & $\mathrm{EBF}$ & $\begin{array}{r}\text { Eccentrically braced } \\
\text { frame with horizontal } \\
\text { link }\end{array}$ \\
\hline \multirow{3}{*}{ R4VEBF } & $\begin{array}{r}\text { First } \\
\text { Character }\end{array}$ & $\mathrm{R}$ & $\begin{array}{r}\text { Frame with isolated } \\
\text { base }\end{array}$ \\
\hline & $\begin{array}{r}\text { Second } \\
\text { Character }\end{array}$ & 4 & Number of the \\
\hline & $\begin{array}{r}\text { Third } \\
\text { Character }\end{array}$ & VEBF & $\begin{array}{r}\text { Eccentrically braced } \\
\text { frame with vertical } \\
\\
\text { link }\end{array}$ \\
\hline
\end{tabular}

\section{4- SEISMIC ISOLATORS}

Design and specifications of seismic isolators in this study were according to journal 360 and 523 [14, 15 and 16] type LRB. Designing natural period of the target is considered as 5.2 seconds. Maximum shear deformation of the rubber bearing $150 \%$, effective damping ratio is $10 \%$ and also effective damping coefficient for $15 \%$ is equal to 35.1 according to the provisions of the guideline. Location of the structure is evaluated with relatively high risk and ground is type 2 . Therefore, in accordance with 2800 standard, acceleration of the plan ratio will be $\mathrm{A}=0.3, \mathrm{~T} 0=0.1, \mathrm{TS}=0.5, \mathrm{~S}=1$. Specifications of seismic isolators for side and middle columns are summarized in table 3 . Hysteresis curves of isolators in each frame is shown in Figure 3. 

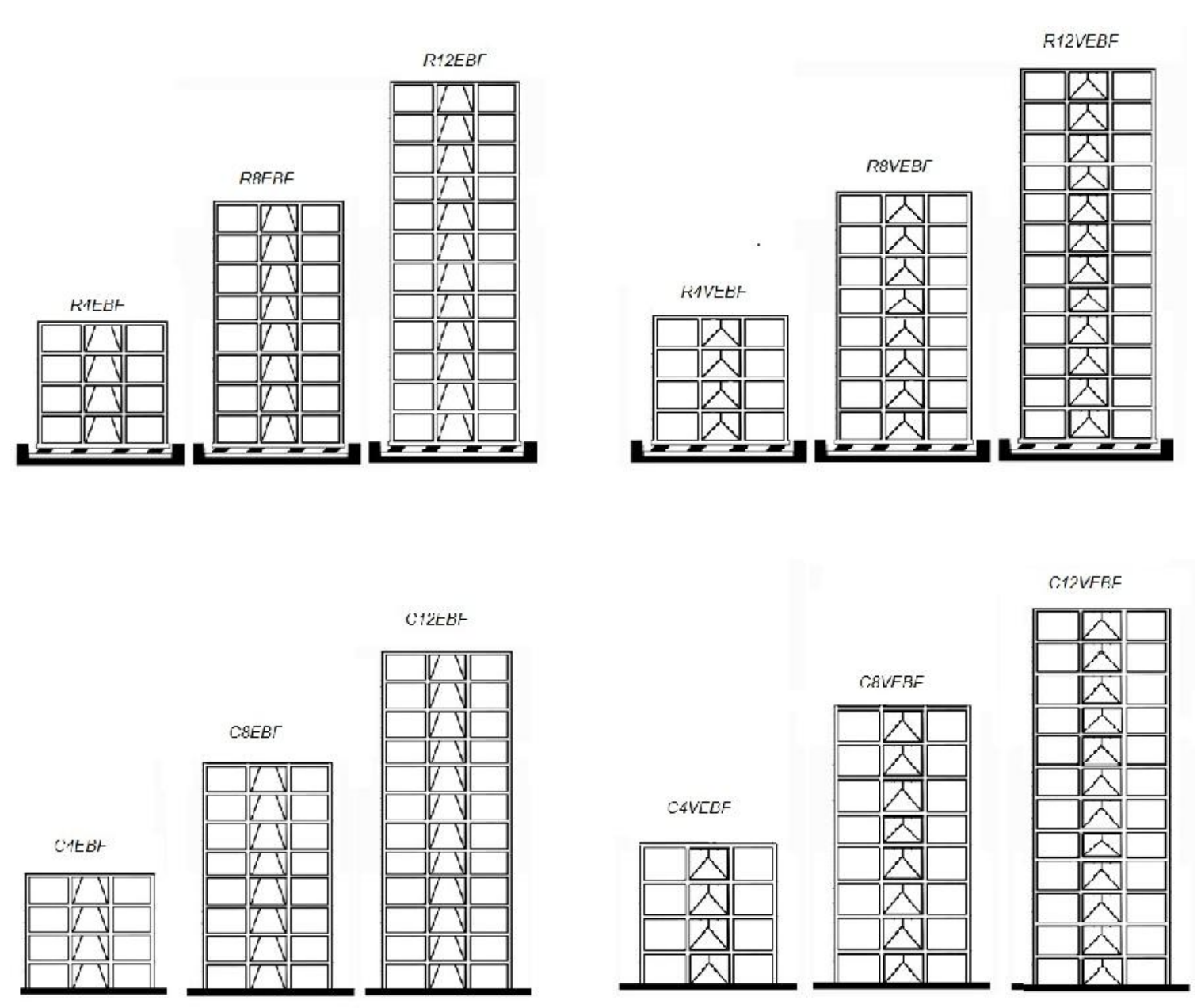

Fig.2. schematic model of eccentrically braced frame with vertical and horizontal links

Table 3. Specifications of seismic isolators for side and middle columns

\begin{tabular}{|c|c|c|c|c|c|c|c|c|c|}
\hline Sid & Stor: & $\mathrm{d}(\mathrm{cm}$ & $\mathrm{h}(\mathrm{cm}$ & I & $\mathrm{t}(\mathrm{cm}$ & Ni & ts $(\mathrm{mm}$ & $\mathrm{t}^{\prime}(\mathrm{cm}$ & $\mathrm{dp}(\mathrm{cm}$ \\
\hline colum & 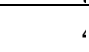 & 0.5 & 53.1 & 51 & 0. & $4 !$ & & ! & 4 \\
\hline \multirow[t]{2}{*}{$\mathrm{ns}$} & : & 0.6 & 53. & 51 & $0 . i$ & $4 !$ & & , & 11 \\
\hline & 1'. & $0 . '$ & 51. & 41 & & $3 !$ & & . & 1 ' \\
\hline Middl & , & 0.1 & 53. & 51 & 0. & $4 !$ & & : & ! \\
\hline colum & : & $0 . '$ & 51. & 41 & & $3 !$ & & : & 1 1: \\
\hline ns & $1^{\prime}$ & 0.7 & $51 .:$ & 41 & & $3 !$ & & . & 1 1: \\
\hline
\end{tabular}

\section{5- HYSTERESIS CURVES OF SEISMIC ISOLATORS}

According to 360 and 523 journals, hysteresis curves of seismic isolators are shown below (Figure 3). 

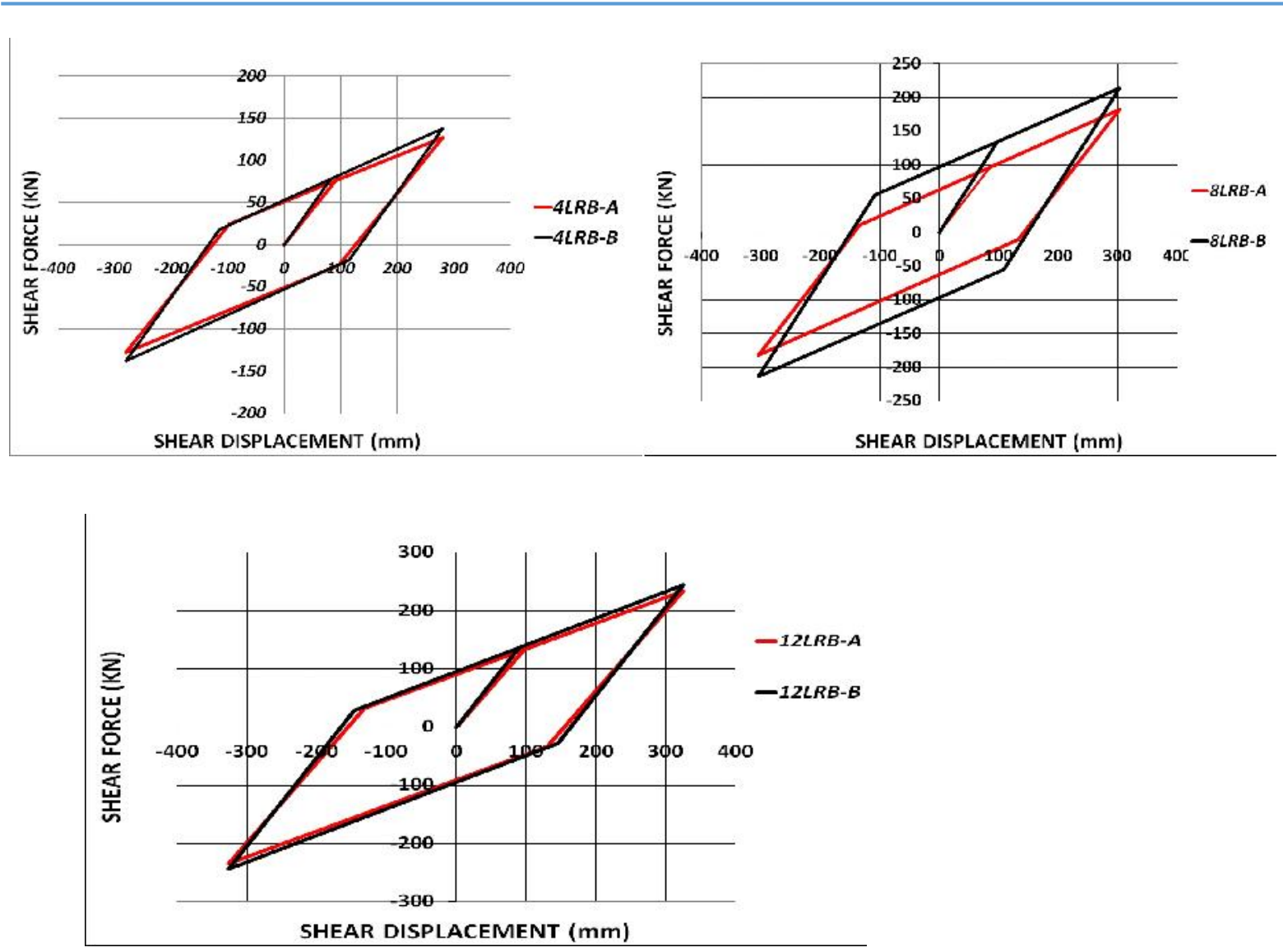

Fig.3. Seismic isolators of side and middle hysteresis curves

\section{6- HYSTERESIS CURVES FOR STEEL FRAMES UNDER VARIOUS EARTHQUAKES}

After applying plastic hinges to the parts and presenting seismic isolators, hysteresis curves are obtained from nonlinear dynamical results. (Figure 4-9)
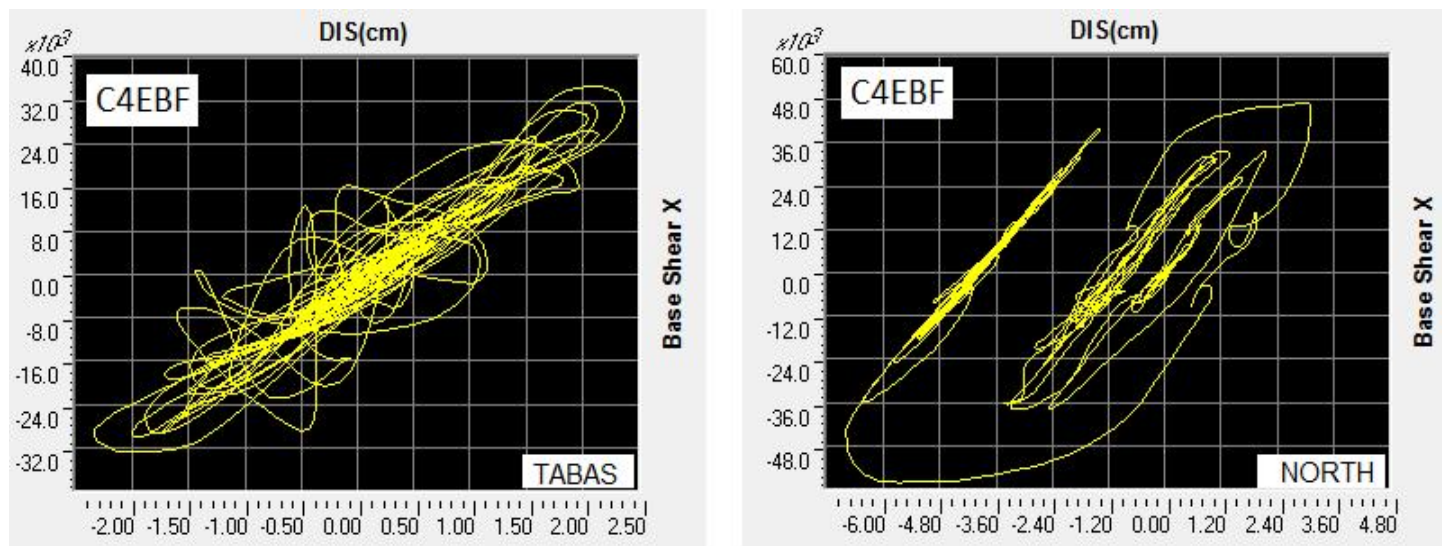

Fig.4. Hysteresis curves of $4^{\text {th }}$ floor frames under various earthquakes 

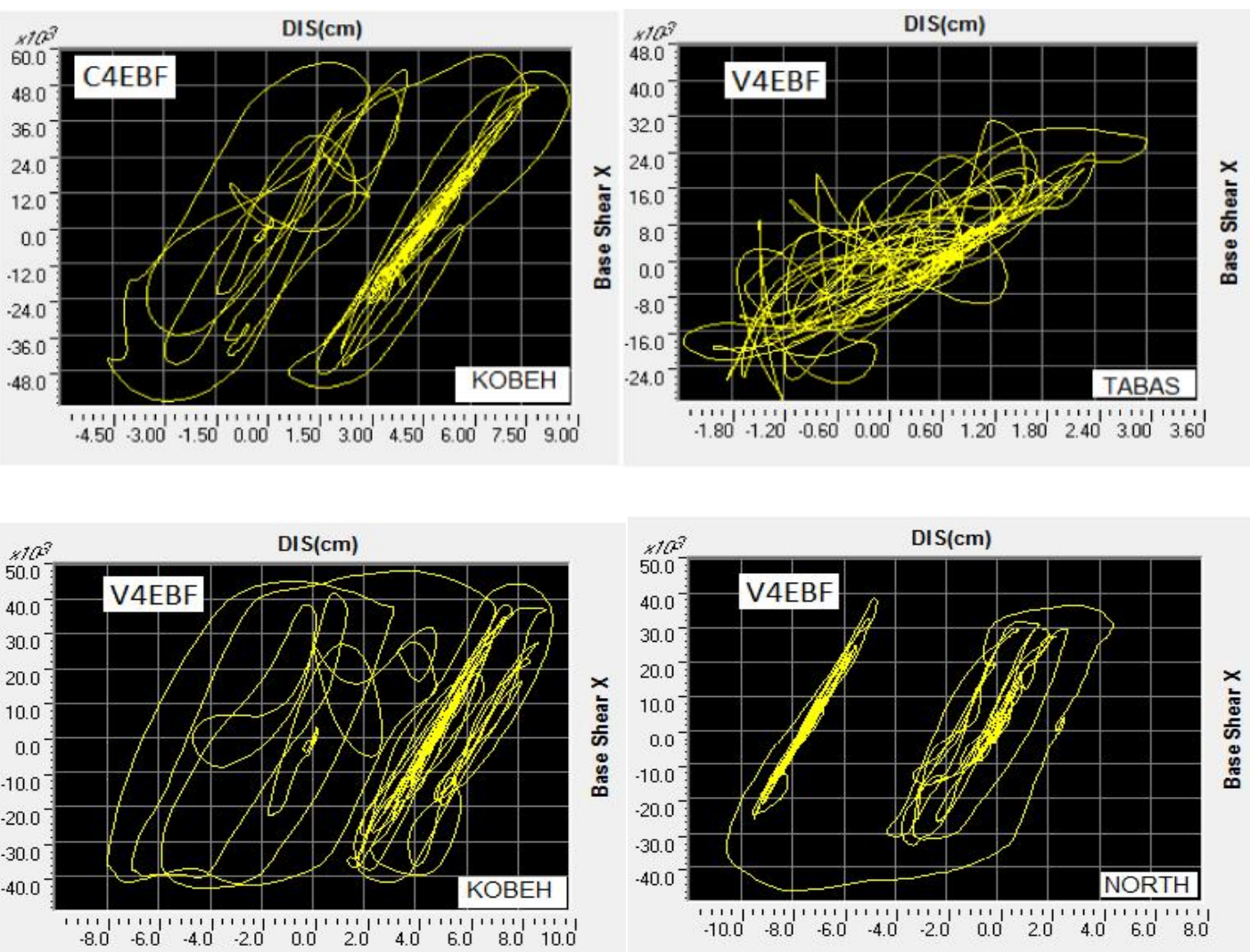

DIS(cm)
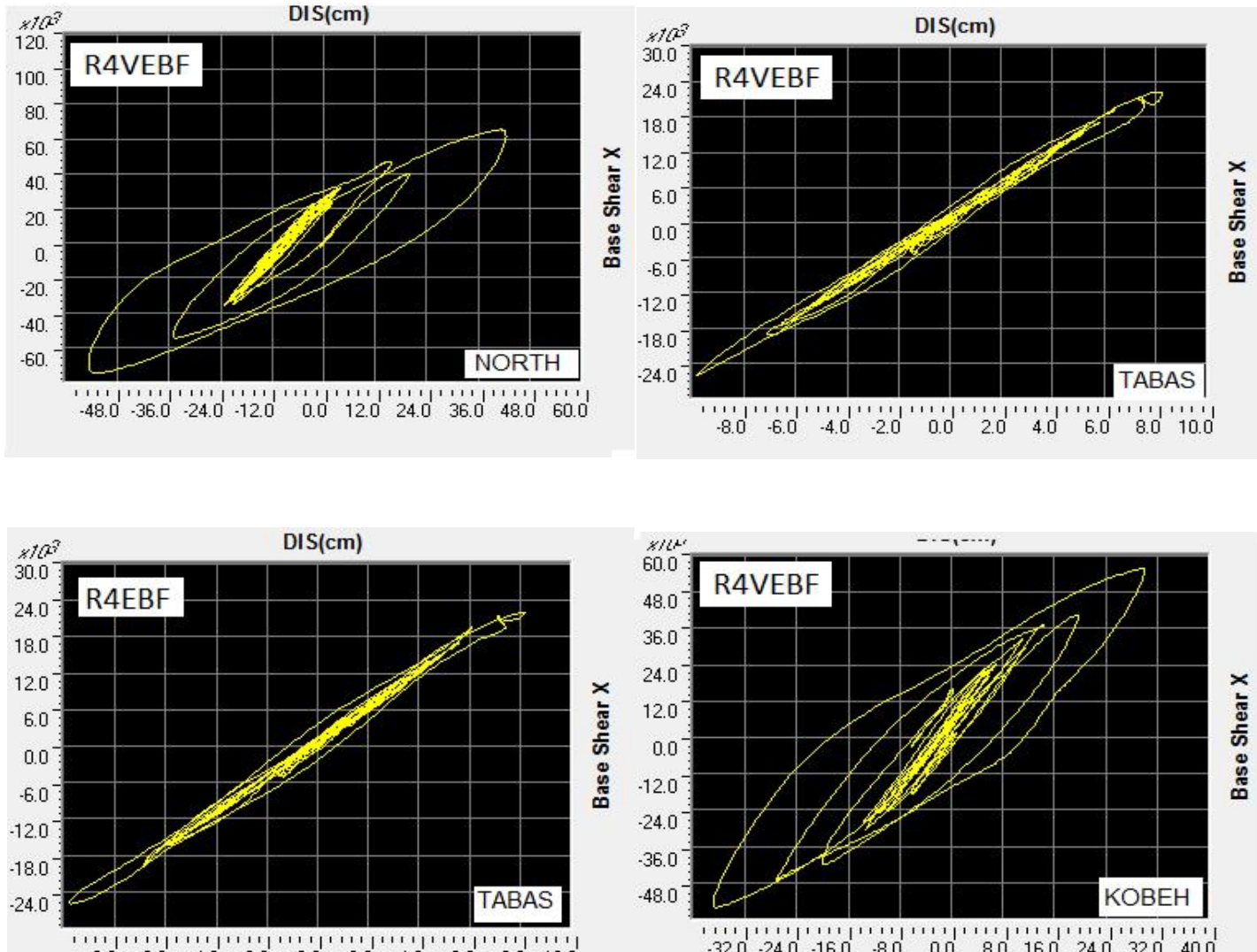

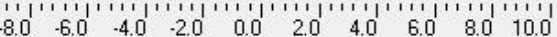

Fig.5. Hysteresis curves of $4^{\text {th }}$ floor frames under various earthquakes 

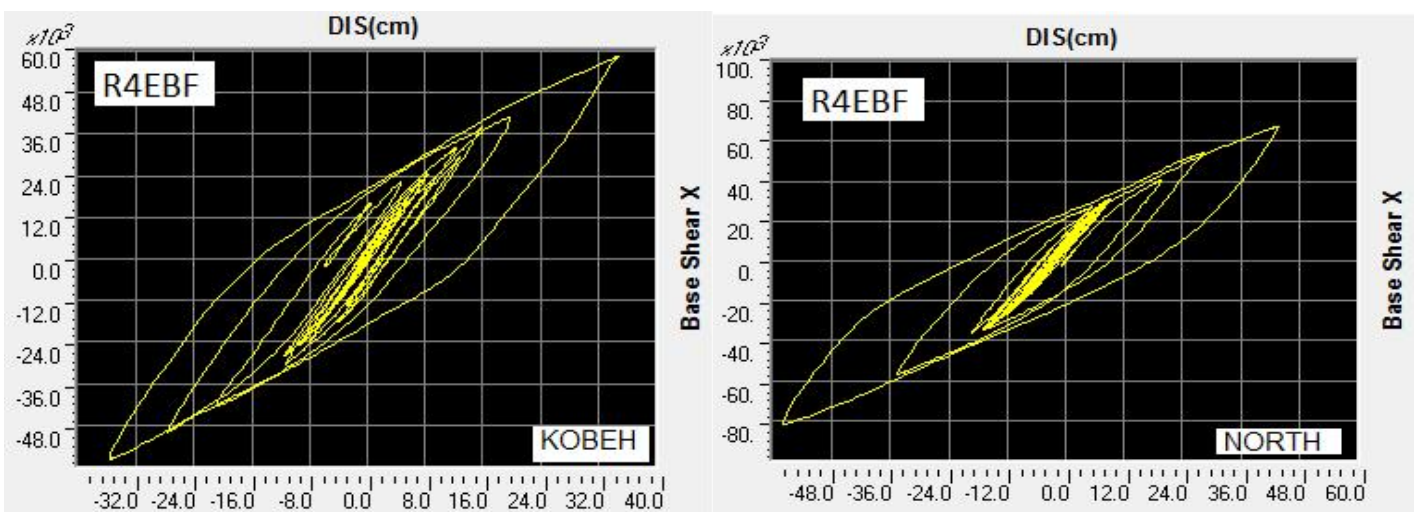

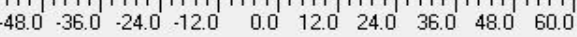
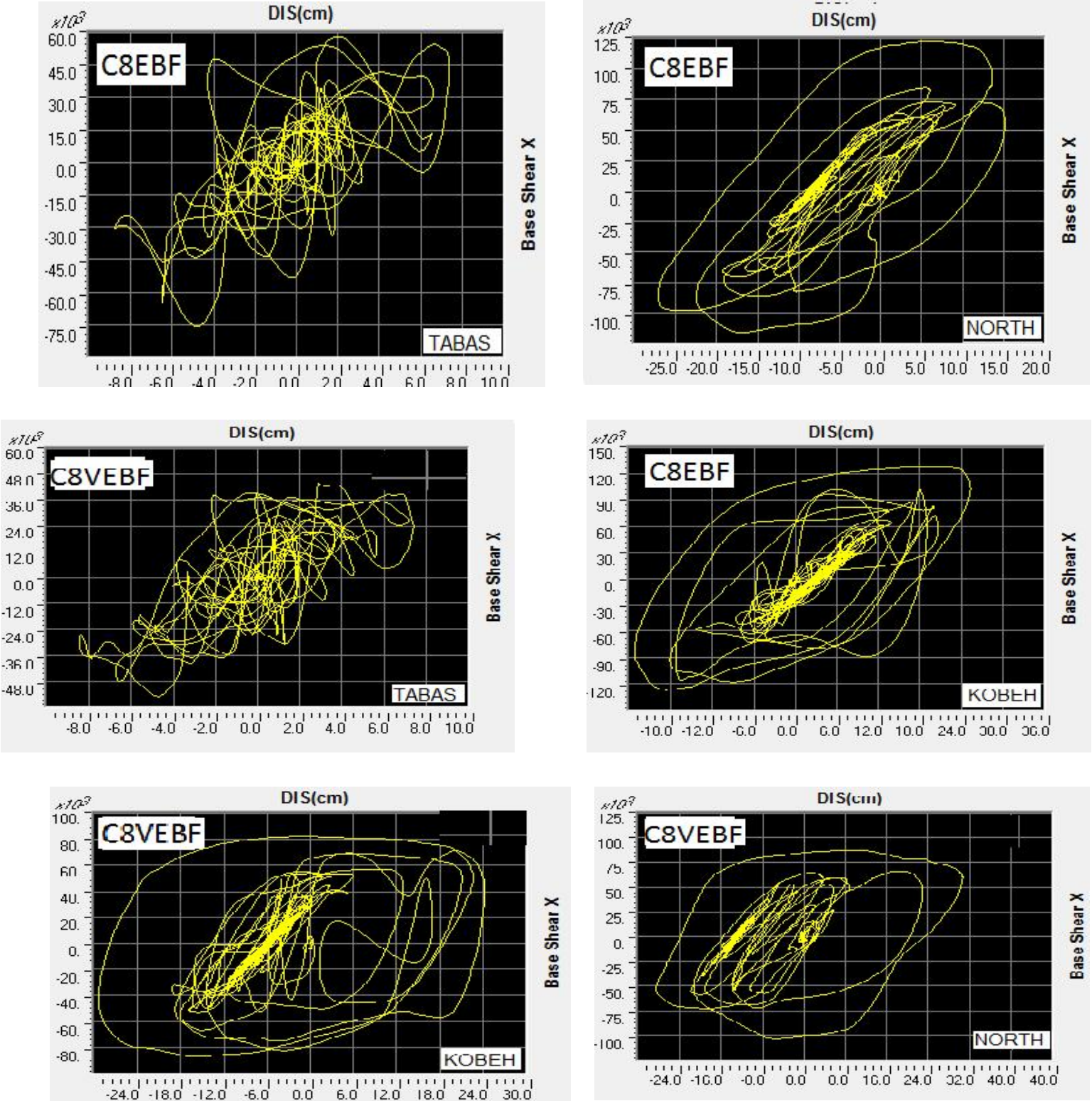

Fig.6. Hysteresis curves of different frames under various earthquakes 

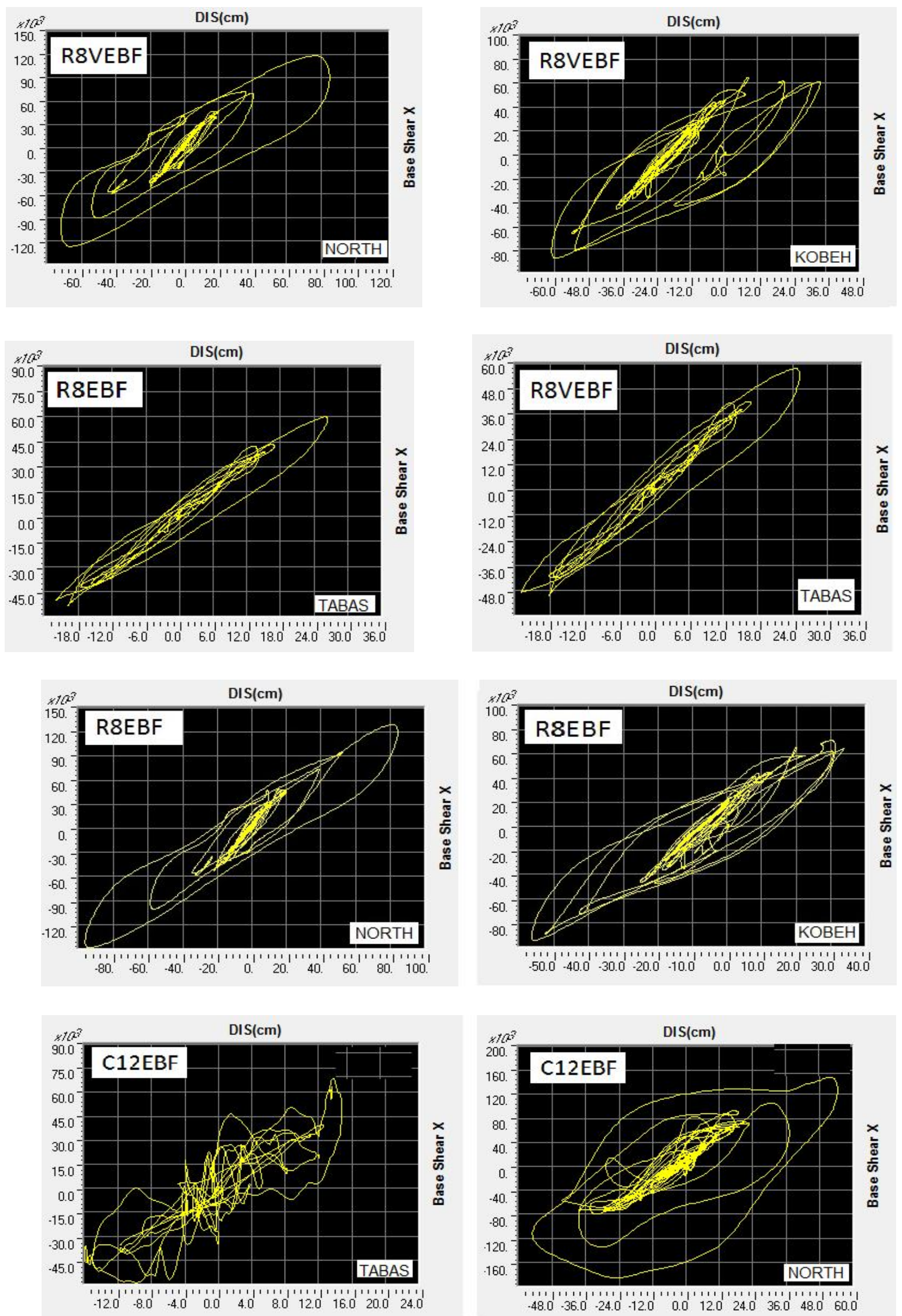

Fig.7. Hysteresis curves of different frames under various earthquakes 

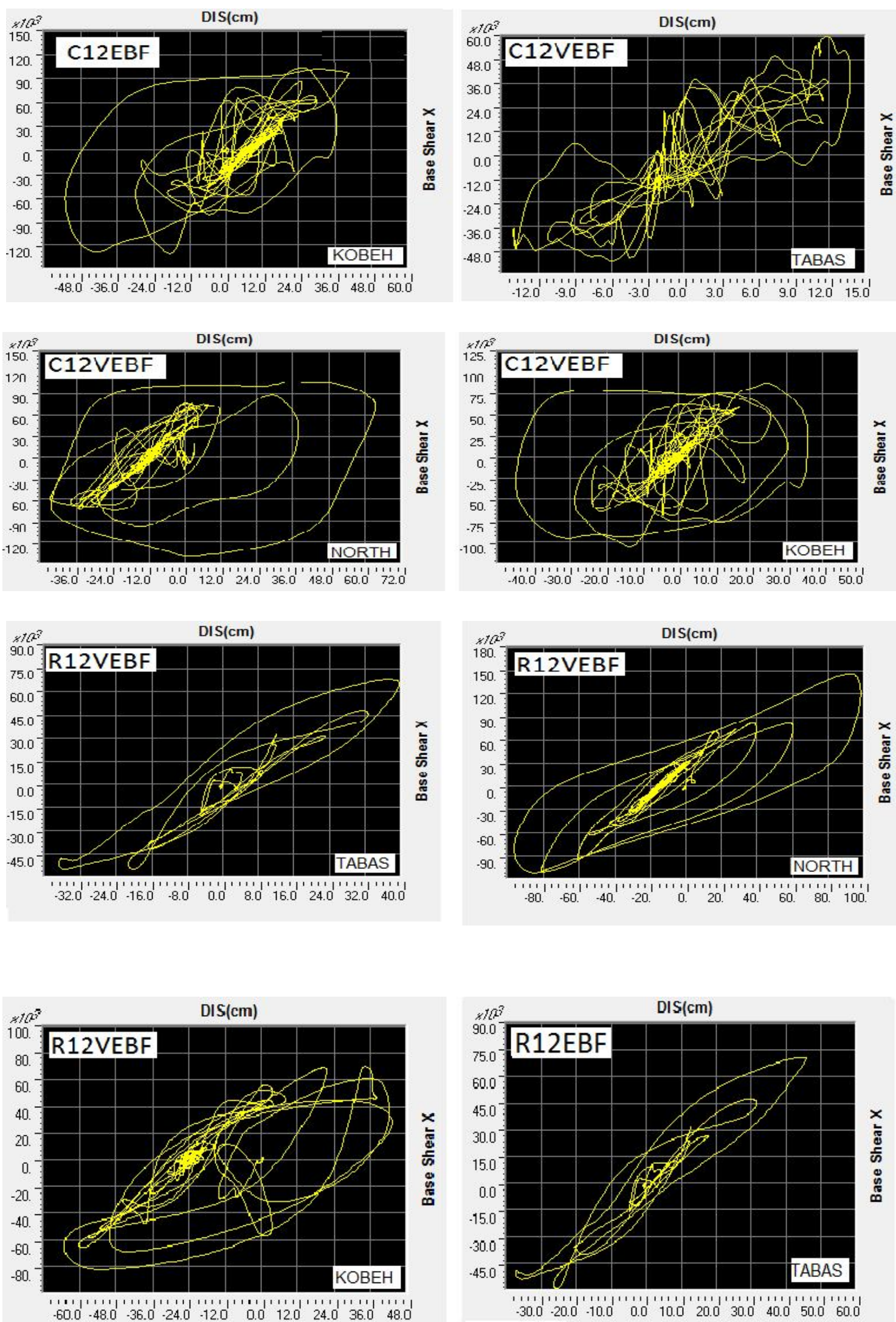

Fig.8. Hysteresis curves of different frames under various earthquakes 

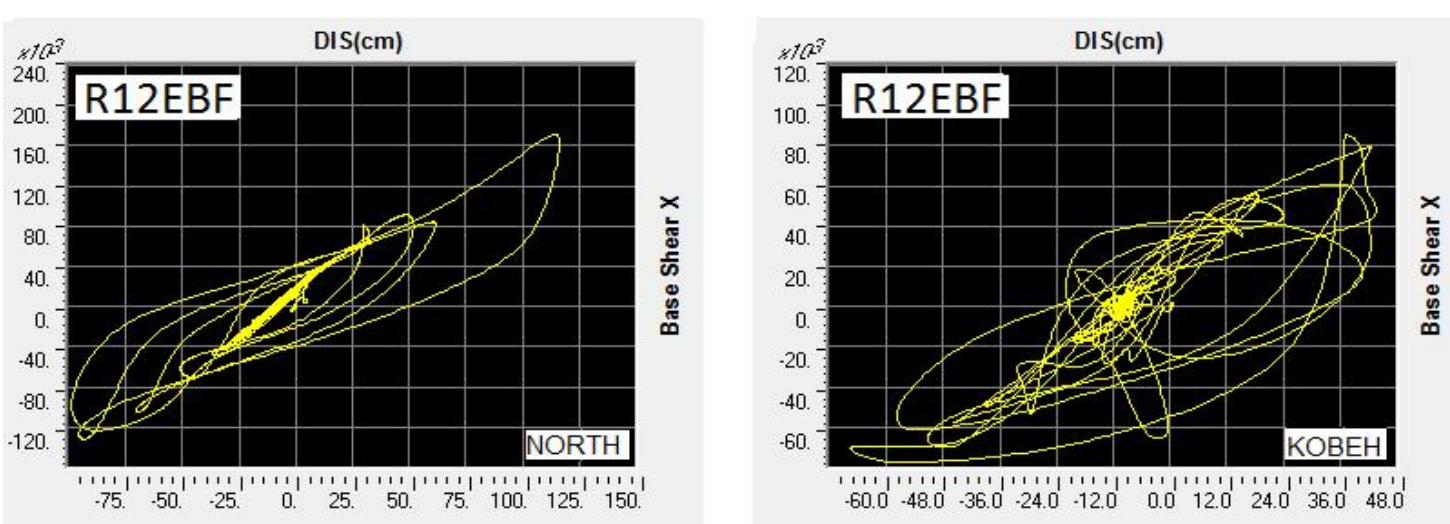

Fig.9. Hysteresis curves of different frames under various earthquakes

\section{7- CONCLUSION}

The followings can be concluded from the above curves:

$>$ Vertical links have higher capacity to absorb energy compared to eccentrically braced frames with horizontal links. Hysteresis curves are also more stable in these frames, and this somewhat confirms the plasticity of this type of frames.

$>$ The results of hysteresis curves indicate that in near-fault earthquakes, a specific confusion can be seen in traditional eccentrically braced frames (with horizontal and vertical links).

Hysteresis curves are relatively same in the frames that have horizontal and vertical links and use seismic isolators.

Hysteresis curves indicate that in the areas near faults, it is better to use seismic isolators in order to regulate the behavior of structure to avoid irregular pulses of near records.

\section{8- REFERENCES}

[1] Shahnazari, H; Negahdar, H; Noori delavar, A; effects of near-fault earthquakes in strucures. $4^{\text {th }}$ national congress of civil engineering, Tehran University, 2008

[2] Barakati, S A; Demand and seismic capacity of steel moment frames affected by nearfault earthquake using increasing analysis dynamics; Thesis of civil engineering Master; Tarbiat modarres University, 2009

[3] Papageorgiou,A.S,The Charactrr of Near Source Ground Motion and Related Seismic Design Issues,Proc. of the Structural Engineers World Congress, San Francisco, California. 1998,pp:18-23. 
[4] Rahimi, S. s. The parameters affecting the pulsed accelerograms in near-fault areas, earthquake engineering master's thesis; University of Abbas Pur 2012

[5] Malhotra P.K "Response of Building to Near-field Pulse like Ground Motion". Earthquake Eng.Struct. Dyn . 1999, 28:1309-1326.

[6] Sabeti, M r., Evaluate and compare the behavior of the coefficient of variation period, formability and increased degrees of freedom in braced divergent systems; master's dissertation, University of Science and Technology, 1998.

[7] Hossein Zadeh, n., an introduction to the use of seismic base isolation, Publications of International Institute of Seismology and Earthquake Engineering, first published in 1995.

[8] Dehvari dehaki, m., A parametric study on the performance level of vertical link beam in steel moment frames using capacity spectrum master's thesis, Islamic Azad University, Zahedan, 2011.

[9] Lohe ghalam, a., The behavior of the type a proposed passive damper, master's dissertation, Tehran University, Tehran 2002.

[10] Among, c., Comparing the relationship between hardness and formability of divergent frameworks in conventional steel structures; "master's thesis, Islamic Azad University, Zahedan, 2010.

[11] Miri, m., Rahgozar-in., Hesami kermani, cross bracing performance-based assessment of horizontal and vertical links in a steel frame, Civil Congress, Amol 2011.

[12] Standing Committee on revising the design of earthquake-resistant building regulations for seismic design of buildings, Building and Housing Research Center Publications, Third Edition. 2007.

[13] International Conference of Building Officials, Uniform Building Code, Structural Engineering Design Provisions, Vol II, April 1997

[14] Deputy of Strategic Executive Office of the technical system. Guidance to design and implementation of seismic isolation systems in buildings; Journal 523, 2010.

[15]Deputy of Technical Affairs, Office of Technical Affairs, the formulation of standards and reducing the risk of earthquakes. The guidelines for seismic retrofitting of existing buildings, Journal 360, 2006.

[16]Deputy of Strategic Executive Office of the technical system; Instructions for seismic retrofitting of existing buildings Journal 361, 2010. 


\section{How to cite this article:}

Dehvari Dehaki M. A, Azmoon P, Azmoon F, Seddiqpour A and Dehvari Dehaki N. Hysteresis behavior of seismic isolators in earthquakes near a fault in eccentrically braced frames with vertical and horizontal links. J. Fundam. Appl. Sci., 2016, 8(3S), 152-166. 